\title{
Carbon Leakage and the Argument from No Difference
}

\author{
MATTHEW RENDALL \\ School of Politics and International Relations \\ University of Nottingham \\ University Park, Nottingham NG7 2RD, UK \\ Email: Matthew.Rendall@nottingham.ac.uk
}

\begin{abstract}
Critics of carbon mitigation often appeal to what Jonathan Glover has called 'the argument from no difference': that is, 'if I don't do it, someone else will'. Yet even if this justifies continued high emissions by the industrialised countries, it cannot excuse business as usual. The North's emissions might not harm the victims of climate change in the sense of making them worse off than they would otherwise be. Nevertheless, it receives benefits produced at the latter's expense. This enrichment is unjust; unjustly-enriched agents ought to make compensation. The best form of compensation is vigorous action against climate change.
\end{abstract}

\section{KEYWORDS}

Climate change, carbon leakage, consequentialism, over-determination

If an aluminium smelter closes in the UK and opens in another country that is not going to make a huge difference to the world of climate change but it is going to make a huge difference to the area where the jobs are being lost because the company has moved.

- British Chancellor George Osborne, September 2013. ${ }^{1}$

\section{INTRODUCTION}

Critics of curbs on carbon emissions often argue that they will simply prompt a rise in other countries' emissions, cancelling out any benefits. Warnings about

1. Quoted in Elliott, Thomson and Sylvester (2013). 


\section{MATTHEW RENDALL}

'carbon leakage' played a prominent role in the US Senate's opposition to the Kyoto Protocol (Davidson, 2008: 75-77; Eckersley, 2010). Senator Frank Murkowski wrote that production would shift to the industrialising countries, and that 'even a modest increase in greenhouse gas emissions per capita in those countries will negate any sort of action taken elsewhere under the Kyoto Protocol or similar agreement' (2000: 358). 'We won't even get reduced carbon emissions', argued Senator Wendell H. Ford of Kentucky. 'That's because every ton of reduced emissions in the United States and other developed nations will be made up - and then some - in the developing world' (quoted in Davidson, 2008: 77).

The Kyoto Protocol was deeply flawed, as many, even among its supporters, agree. Yet the Senate proposed nothing substantial in its place. Kyoto's critics often seemed to assume that the treaty's faults justified Washington in doing next to nothing. ${ }^{2}$ The arguments resurfaced before the Copenhagen climate change summit of 2009. 'Mr Obama', advised the Wall Street Journal, 'can opt to impose a huge carbon tax and drive jobs overseas, or he can impose the tax along with a tariff, and kick off a trade war. Better to call the whole thing off' (2009c). Two years later British chancellor George Osborne remarked that 'We are not going to save the planet by shutting down our steel mills, aluminium smelters and paper manufacturers. All we will be doing is exporting valuable jobs out of Britain' (quoted in Harvey, 2011).

Most philosophers - and many policymakers - agree that the world should be doing more to prevent climate change, and that the rich industrialized countries should bear most of the burden (Baer, 2011: 326; Gardiner, 2011: 29 n.22). Many of their opponents doubt that anthropogenic global warming is occurring at all - or that its effects will be bad enough to justify taking action. But they have also warned that mandatory reductions in the North will cause emissions to migrate to Southern countries whose industry is less efficient (Murkowski, 2000: 353; Coon, 2001). The Wall Street Journal claimed that 'A cap-andtax plan would be the greatest outsourcing boon in history', and might 'even increase $\mathrm{CO}_{2}$ emissions overall, because the developing nations where businesses are likely to relocate ... tend to use energy less efficiently than does the U.S.' (2009a). The argument, then, is that even if emissions-cuts are desirable, it is pointless to act unless the South does as well.

Presented as an excuse for business as usual, this appeals to what Jonathan Glover has called 'the argument from no difference': that is to say, 'if I don't do it, someone else will' (1975: 172). ${ }^{3}$ While American critics warned that curbs on emissions could raise costs for carbon-intensive industries, encourag-

2. Murkowski, for example, insisted that 'any actions to address climate change must be voluntary and without substantial economic cost' (2000: 358).

3. Glover writes that the term also refers to claims that 'One person makes no difference', such as those made when excusing one's failure to vote. This seems a distinction without a difference. Such reasoning likewise appeals to overdetermined consequences- 'Even if $I$ don't vote, enough others will'. 
ing them to migrate, this is not the only way that carbon leakage could occur. By consuming fewer fossil fuels, the North might cause their prices to fall, encouraging more consumption elsewhere. Deep cuts could also reduce the felt urgency of the threat posed by climate change, encouraging other states to freeride off the North's efforts (Posner and Weisbach, 2010: 81; Pearson, 2011: 150-51, 181). Indeed, much of the rise in emissions from China, and other industrialising countries, results from producing goods for export to the industrialised world (Goldenberg, 2014), although this shift can occur for different reasons, such as industries migrating to take advantage of cheaper labour and other favourable conditions (Eckersley, 2010: 371).

This paper makes two assumptions: that the world ought to be doing more about climate change, and that without a binding global-emissions regime, any cuts by the North will be cancelled out by carbon leakage to the South. In reality, the premise that 'carbon leakage' will completely offset emissions-cuts is dubious. Many studies suggest that only a minority of emissions leak to other countries. Moreover, policy can be designed to minimise leakage. Emissionscurbs could, if necessary, target sources that cannot 'migrate', such as cars (Davidson, 2008: 77; Eckersley, 2010: 376-78; Pearson, 2011: 151-56). ${ }^{4}$ Nevertheless, it is worth examining what it would mean if the premise were true. Glover notes that any number of seemingly odious acts - from developing chemical weapons to dealing heroin - could be defended by claiming that 'if I don't do it, someone else will'. This argument may cut no ice with deontologists. If rights take the form of 'side constraints', and may not be violated even in order to bring about outcomes that are better, or fairer (Nozick, 1974: 28-29), then the fact that someone else would have committed the unjust action in the agent's place seems neither here nor there.

Those who criticise carbon mitigation on the grounds that it would make no difference are arguing along consequentialist lines, however, and for consequentialists it is harder to put one's finger on where it goes wrong. The most obvious reason to condemn heroin dealers or chemical-weapons scientists is that they harm people. But if others would have done the damage anyway, then it is not clear that they do harm people, in the sense of making them worse off than they would otherwise be. This conception of harm can be challenged (Norcross, 2005). Still, 'it is hard', as Glover observes, 'for those of us who think that moral choices between courses of action ought to be determined, either largely or entirely, by their different outcomes, to explain what is wrong with such a defence' (1975: 171).

This paper gives a consequentialist answer. It explores the argument from no difference, and finds that the actions which it is invoked to defend typically

4. Carbon leakage will, moreover, have some desirable effects; on the whole, it will benefit poor countries at the expense of rich ones. That carbon leakage will improve the international distribution of resources is not an argument in its favour, however, that the US Senate or the Wall Street Journal would accept. 


\section{MATTHEW RENDALL}

involve unjust enrichment. Agents may engage in harmful practices without themselves causing any damage that would not have occurred anyway. But the only reason to do so, short of sheer perversity, is to benefit themselves, or third parties about whom they care. No one can reasonably deny that climate change threatens millions of people with severe injustice. This injustice arises through the industrialised countries' emissions. Even if these high-emitters cause no harm, they greatly benefit. Unjust enrichment obliges beneficiaries to disgorge the gains. If wisely used, these resources could do much to fight climate change.

\section{WHAT'S WRONG WITH THE ARGUMENT FROM NO DIFFERENCE?}

Most discussion of Glover's seminal essay has focused on what he called 'the argument from the insignificant difference': that there is no reason to act, or refrain from acting, when the effects will be too small to make a difference on their own (1975: 172). Philosophers have widely debated whether individuals' carbon emissions are harmful, and, if not, whether they can be wrong. The argument from no difference has attracted less attention. Yet it probably plays a bigger role in debates about states' duties to curb their emissions. Whereas one cannot plausibly claim that a whole country's emissions are too small to make a difference - at least those of a large one like the United States - it is often claimed that reductions in one country will simply cause them to rise in another. Let's call this the Global Warming Argument from No Difference (GWAND). What can be said against it?

Here it will be helpful to consider one of Glover's examples, originally formulated in a famous essay by Bernard Williams (1973: 97-98). George, a young chemist, is struggling to get a job, and this is placing severe strain on his family. A colleague offers to get him a post in a chemical- and biologicalweapons laboratory. When George says that he opposes these weapons, the colleague responds that if George does not take the job, it will go to another, less scrupulous researcher, who will likely make more progress in the research than George would. George's wife, who is struggling to support the family, has no particular objections to the research. George faces a decision structurally identical with the decision faced by rich emitters, at least to hear the Wall Street Journal tell the story. If he takes the job, he will not harm any of the victims of chemical weapons, in the sense of making them worse off than they would otherwise have been. Indeed, some people will be better off than if the other eager-beaver researcher had received the job. Analogously, according to extreme versions of GWAND, for the industrialised countries to restrict their carbon emissions would actually exacerbate global warming. If George should 
refuse the job - or the North cut its emissions - the reason cannot be, given these assumptions, that the alternative will make things worse.

Even when harm would have occurred anyway, we can criticise an agent for inflicting damage, provided that she could not have foreseen that someone else would act harmfully in her place. Shooting someone is usually wrong, even if it turns out that someone else would have killed the victim. We may also blame her if she could have dissuaded other actors from carrying out the harmful action (Jackson, 1997). George, however, knows that the other chemist will take his place, and nothing he says or does can change that. ${ }^{5} \mathrm{~A}$ somewhat more cogent objection to his taking the job is that it might prevent him from engaging in some other work of value. But George can't be sure he will get any other job, and in any case the objection to the chemical-weapons work can hardly rest on the fact that it will stop him from doing the greatest amount of good in the world possible. George would also do less good than he possibly could if he chose to run a pool hall. If that is the extent of the objection, then it is a pretty weak one (Williams, 1973: 100; Glover, 1975: 177-79). In any case, this objection applies only to actions with an opportunity cost. Burning lots of coal does not prevent countries from doing good things; indeed, it often enables them to do so. While it might be better for poor countries to enjoy these advantages than the rich ones, this does not seem to get at the central objection to the latter's choice to go on emitting heavily themselves.

A stronger objection to George's taking the job is that it is likely to discourage him from taking a stand against chemical weapons. It may be hard to work at a job whose direct effects are death and destruction, even if he knows they would occur anyway. George may convince himself that chemical weapons are not so bad after all. Nor will he be taken very seriously if he speaks out against the chemical-weapons industry (see Glover, 1975: 178). By accepting the job, George may also violate what is usually a very good moral rule - don't take jobs that usually harm people. For a number of reasons, agents are likely to do better in the long run by following such good principles, except in extraordinary circumstances, than by trying to maximise benefits in each case. Notably, they must worry that they will be tempted to rationalise self-serving decisions as optimal, even in cases where they are not. With some actions, such as torture, it may be better not even to consider making exceptions (Hare, 1965: 43-45; Hare, 1981). While here it has been stipulated that accepting the job will make things go best, George himself cannot be sure of that, should be mistrustful of his own motives, and might well act rightly - subjectively speaking, at any rate - in turning it down.

5. If this stipulation seems unrealistic, we can add that there are enough unscrupulous chemists on the job market that one of them is bound to take George's place. Analogously, defenders of GWAND could argue that if China does not replace the United States' emissions, then India will. 


\section{MATTHEW RENDALL}

Moreover, the best moral code is arguably one that agents share, and that allows them to monitor each other's compliance and punish violations. This precludes building in too many exceptions, because without extremely detailed knowledge of the circumstances, it would be often hard to tell whether agents deserved praise or condemnation (Johnson, 1991: 209-19). Joining a chemical-weapons lab is ordinarily a harmful thing to do, or so we have assumed. ${ }^{6}$ A society with an optimal set of norms will condemn anyone for doing so, even though in this case it will make no difference. Indeed, if George is a good person who has internalised this code, then he ought to have reservations about taking the job. Liam Murphy has made this point well with a different example. Suppose your job requires you to wear an expensive suit. One day you pass a lake and see a drowning child. You can save the child at the cost of ruining your suit, or you can write a cheque to Oxfam that saves two children for the sum you would pay to replace it. If you had no reservations at all about abandoning the child, consequentialists would rightly conclude that there was something badly wrong with you. It would be the sign of a pathological character; you would have to lack motives highly desirable for agents to have, and you could well be blamed for failing to develop them. Perhaps you could justifiably conclude that it was best to write the cheque and let the child drown, but you ought at least to feel torn up about the decision (Murphy, 2000: 128-33). Similarly, it may be that, all things considered, George should take the job. But there would be something wrong with him if he felt that it was the obvious thing to do. While Williams considered this a weighty objection to utilitarianism, it can be explained by motive consequentialism (Williams, 1973: 99; see also Adams, 1976).

George must worry, then, that the job will corrupt his motives and undermine his ability to work for good causes. He should also be suspicious of his own motives for violating what is normally a good rule, and his peers will rightly have doubts about his decision. Finally, if he has developed the right moral reflexes, he should feel reluctance and aversion to the job, even if he concludes that it is best to accept. To a greater or lesser extent, all these considerations apply to GWAND. The North has reason to feel reservations - and other states have reason to feel some suspicion - about its choosing to violate the generally desirable rule against practices that damage other countries. A country that has cultivated the right 'green virtues' should also feel a visceral aversion to polluting (Jamieson, 2007). Most importantly, staying hooked on fossil fuels risks corrupting the industrialised countries' motives, and discouraging them from pursuing alternatives (Gardiner, 2011). Nor will they be able to demand sacrifices from other states as credibly as they otherwise would. The danger that ongoing high emissions will undermine Northern states' ability to work for change - assuming, of course, that they have any interest in doing so

6. In contrast to biological weapons, it is not obvious that chemical weapons-which is presumably what George would be working on — are worse than conventional ones. See Price, 1997. 
- is actually greater than in George's case. George might, after all, have little influence (Williams, 1973: 107; Glover, 1975: 179). The same cannot be said of the United States.

Nevertheless, let us stipulate that if George takes the job, or if the industrialised countries go on polluting, they will do less harm than if others took their place. Under these circumstances, refusing might seem self-indulgent (Silverstein, 1979: 350-58). George's wife, who is struggling to keep the family above water, may have little sympathy with his scruples. Voters in industrialised countries are apt to have very little time for the claim that they must sacrifice jobs and living standards, unless worldwide emissions will actually go down. Finally, if industry simply migrates, those states that exercise restraint are apt to lose resources and power to states with fewer environmental scruples. In a tragedy of the commons, appeals to voluntary self-restraint risk undermining the very attitudes we seek to promote, by increasing the influence of actors unresponsive to the norm (Hardin, 1968/2009: 249-50).

All things considered, given the stipulated assumptions, George might defensibly accept the job, and the North might maintain its emissions. But the story does not end there. The argument from no difference has a feature its analysts have hitherto overlooked: unjust enrichment. If George takes the job, or if the industrialised countries go on emitting, then they will profit from an injustice, and they will act wrongly if they keep all of the gains.

\section{UNJUST ENRICHMENT}

Beneficiaries of unjust enrichment do not always cause the original injustice. Nevertheless, they act wrongly by retaining the gains. Agents can be blamed if they are aware - or should have been aware - that they have benefited unjustly, and if they could disgorge the benefits, but fail to do so (Brooks, 1989: 36; Anwander, 2005: 42). If he takes the chemical-weapons job, George will earn a good salary. True, if he did not do the work, someone else would. 'How can George benefit at the victims' expense', it might be asked, 'when they would have suffered the same harm if he had refused the job?'7 Even if we grant that George will not benefit at their expense, benefits will be unjustly produced at their expense - benefits of which he will be the recipient. Similarly, Northern states are using far more than their fair share of carbon emissions, by any reasonable standard. This process entails, in Steve Vanderheiden's words, 'the shifting of the ecological costs of the high-consumption lifestyle of the world's affluent onto those who can least afford to bear them, are least responsible for

7. Harry Silverstein argues that in such cases the agent is not even causally responsible: 'since nothing he can do will prevent it, he does not cause it' (1979: 355). Carolina Sartorio, in contrast, maintains that when one agent's action pre-empts another's, the first remains causally responsible (2006: 531). 


\section{MATTHEW RENDALL}

producing them, and have received the least advantage from them'. It means unjust enrichment (Vanderheiden, 2008: 45-46, quotation at 45; Page, 2012).

Unjust enrichment is related to another form of injustice: exploitation. Both can occur without making the victims worse off: they are often, in Joel Feinberg's felicitous phrase, forms of 'harmless wrongdoing' (see Feinberg, 1988). Indeed, workers typically benefit from being exploited; otherwise, they would not accept the job. The real objection is not that exploitation harms them, but that they do not benefit as much as they deserve (Mayer, 2007: 141; see also Feinberg, 1988: 176). Yet most consequentialists will agree that both unjust enrichment and exploitation, other things being equal, make outcomes worse. Some will hold that they introduce independent elements of badness, whereas others will see them as reducing the moral value of utility that would be worth more if fairly distributed (see Feldman, 1995a; Feldman, 1995b; Vallentyne, 1995). Consequentialists can object to George's taking the job, or to industrialised states' high emissions, on the ground not that they are harmful, but that they are unfair.

Note that unfairness arises in these cases through actions occurring in the present. Some climate philosophers have sought to base the charge of unjust enrichment on industrialised states' excessive past emissions (Gosseries, 2004; Page, 2012). This claim, when applied to the distant past, seems to fall foul of the 'non-identity problem'. Decisions about energy have an effect upon which people are born. If our ancestors had not mined coal and burned oil, hardly any of us would be here; they would have met and mated with different people and at different times, and genetically-different people would have been born instead of us. This makes it hard to argue that the present-day inhabitants of the North are better off than they would otherwise be because of emissions that occurred before they were born. Had those emissions not occurred, they would not be worse off; rather, they would not exist at all (Caney, 2006: 475-76; compare Das, 2014). Nevertheless, because of the world's current high emissions, today's rich countries enjoy more resources and welfare than they deserve, and future people will receive less. And for purposes of making that claim, the latter's identity is irrelevant. If I take more than my fair share of pie, leaving the next person who comes to the table with less, then I act unfairly even if my act results in a different person having pie. My act does not change my identity, and we can still say I have benefited unjustly. Analogously, even if present emissions will not harm our descendants in the sense of making them worse off than they would otherwise be, consequentialists can condemn the current unjust enrichment of the industrialised countries at their expense. The expected outcome is thus worse than if the same quantity of utility were distributed as it should be (Rendall, 2011b: 244-45; Lawford-Smith, 2014). In fact, a strong case can also be made that the inhabitants of the industrialised countries have benefited, and continue to benefit excessively from these emissions ever since each of them was born (Meyer and Roser, 2010: 234-35; Page, 2012: 320). 
Nevertheless, the benefits from their present emissions are quite enough to ground a claim of unjust enrichment.

None of this proves that George should refuse the job, or that the industrialised countries should slash their emissions. If carbon leakage will be severe, then slashing emissions will not prevent the injustice - it will mean that other agents scoop the gains instead. The mistake of the argument from no difference is a different one - to assume that this justifies performing the action and keeping all the gains. In fact, if one cannot prevent unjust enrichment, the next best thing is to rectify it. This often means compensating the victims. George could donate part of the salary from his new job to a fund for the victims of chemical weapons. Likewise, it may do more good for the North to continue its high-emitting activities, but use part of the profits to assist victims of climate change with adaptation. Nobody, however, has yet been killed by George's research, and most of the damage from climate change is yet to come (Posner and Weisbach, 2010: 108). George has a means of reducing the chance that people will be harmed at all: he can use his earnings to lobby against chemical warfare. Rectification sometimes involves using the unjust gains to put an end to the injustice (Brooks, 1989: 41-42). Similarly, the best way to help prospective victims of climate change may be to see that less of it occurs in the first place. That includes assistance to poorer states in reducing their emissions, and research into alternative energy sources. It could also mean side-payments to industrialising countries to gain their accession to a cap and trade regime.

\section{DOES THE CLAIM OF UNJUST ENRICHMENT MAKE SENSE?}

In an important new paper (2015), Robert Huseby criticises the view that the beneficiaries of unjust enrichment bear a special duty to compensate the victims of the act from which they benefited. Suppose that climate change resulting from the emissions of the industrialised countries causes droughts, crop failures and famine in the Sahel. Imagine that at the same time, an unprovoked invasion of Congo by its neighbours causes crop failures and famine there. People are starving in both regions through no fault of their own. Congo's neighbours, moreover, are neither able nor willing to relieve the famine, nor is there any prospect of their doing so in the future. Suppose, finally, that by assisting Congo, the rich countries could save more lives. If agents must compensate the victims of acts from which they have unjustly profited, then the rich countries should give priority to the Sahel. This may seem implausible.

Huseby notes that when an agent has caused harm, it might be held that she has an obligation to compensate that act's specific victim. But that is not the case here; we are assuming that if the industrialised countries had not done the emitting, China would have done so in their place. The rich countries ought to make compensation, not because they have harmed the Sahel, but because they 


\section{MATTHEW RENDALL}

are enjoying more than their fair share of benefits. The rationale for compensation is thus to rectify a distributive injustice. But surely if one innocent person starves in Congo, it is just as unjust as if one person starves in the Sahel. Why should the Sahel have a stronger claim to be compensated simply because the beneficiary of the acts which caused the damage happens to be able and willing to pay compensation? (Huseby, 2015: 218-20). Assisting the Congo would save more lives, and also redress more injustice.

This objection could be met by broadening the principle to hold that 'beneficiaries from unjust acts have special duties to compensate any victim of injustice' - what Huseby refers to as the 'Generalized Beneficiary Pays Principle', or GBPP. We could then conclude that insofar as the industrialised countries have benefited unjustly from carbon emissions, they may use this surplus to relieve injustice in either the Sahel or Congo. Suppose next, however, that an earthquake strikes Ethiopia, again resulting in crop failure and starvation. The GBPP, Huseby argues, has the implausible implication that in such cases the beneficiaries of injustice have more reason to help the victims of human injustice than of natural disasters (2015: 221). It would tell them to assist Congo rather than Ethiopia, even if they could do more for the latter, and this despite the fact that they were responsible for neither country's suffering.

This implication is certainly implausible, but we need not abandon the concept of unjust enrichment, or the principle of disgorgement. Rather, we should accept that suffering a natural disaster can be a form of injustice. Robinson Crusoe may have suffered no injustice through being shipwrecked. But the plight of the Ethiopians is not like that: if nobody helps them, they will be avoidably worse off through no fault of their own. When industrial countries emit more than they would be allowed if all states were doing their share, their residents enjoy more than their fair share of welfare. The inhabitants of all three regions in our story enjoy less. Justice is often equated with fairness; fairness requires the satisfaction of claims according to their strength (Broome, 1990/91: 95). Starving people in all three regions have equal claims on the rich countries' assistance, insofar as they are equally badly off through no fault of their own, the rich countries are better off than they deserve to be, and the latter could redress the imbalance. The most that Huseby's critique shows, then, is that the North might also make up for its unjust enrichment by assisting other innocent victims. ${ }^{8}$

8. A number of writers, most recently John Broome (2012: 13-14, 66-67), have maintained that for those concerned with maximising value, there are options more cost-effective than carbon mitigation. Since runaway climate change might result in the permanent impoverishment of the planet, this argument is plausible only if we greatly discount the future. Particularly if we give significant weight to the existence of higher forms of sentient life in the far future, reducing the small risk of the extinction or the collapse of these populations has enormous expected value, as Broome's own comments in an earlier essay suggest (2010: 108-10; see also Kent, 2004: 164). While the North might make up for its unjust emissions by investing in other projects, carbon mitigation is one of its best options. 
One might think that this stretches the concept of unjust enrichment to the breaking-point. Why not just say that Northern states owe assistance because of the harm they are causing as polluters, or because of their ability to pay (Huseby, 2015)? The polluter-pays principle presupposes that the polluter must make compensation in proportion to the harm it has caused (Vanderheiden, 2008: 67). If carbon leakage would be extensive, however, much of the North's present emissions do not cause harm in the sense of making global warming worse than it would otherwise be. To base the North's duty of assistance solely on its ability to pay, on the other hand, would entail that even if some rich countries chose to go on emitting at high levels, they would have no greater duty to offer mitigation and adaptation assistance than would equally well-off states with low emissions. But that seems unfair. Even if it were fair, it would be undesirable for practical reasons, since it would give high-emitting states no incentive to reduce their emissions (Gesang, 2011: 59). The latter have an additional responsibility to discharge, which neither the harm that they cause nor their ability to pay seems fully to explain. There appears to be a distinct role for the GBPP, after all.

Some might object that assigning greater responsibility to rich high-emitters is nevertheless unjustified. If an act is permissible, then on what has been called the 'nonworseness claim', any alternative is permissible if it has at least as good an outcome (Wertheimer, 1996: 289-93). Few would hold that George is obliged to take the chemical-weapons job. Similarly, it may seem that if a country slashes its own emissions, it has done enough, even if the emissions migrate elsewhere. Yet if George takes the job and spends his whole salary on himself and his family, or if a rich Northern country goes on emitting and does nothing to offset the consequences, the consequences will be no worse, we have stipulated, than those of either of these permissible acts. The agents of the harm and the beneficiaries of the enrichment will change, but that should be irrelevant for impartial consequentialists. Why should one set of actions be permissible, but not the others?

We can start to address this objection by asking why consequentialists might think that George could permissibly turn down the job. Those who believe that agents must always seek to maximise the good will simply deny that he might (Bailey, 2011: 241-42). George would do more good by taking the job and donating a large share of his salary to some worthy end. Moderate consequentialists, however, hold that people may sometimes give their own goals and interests priority. One justification is that granting this permission makes things go best in the long run. If all of us were obliged to choose our jobs, marry or refuse to marry, spend each penny of our salaries, and so on, on the basis of what would maximise happiness in the universe, we would be very unhappy indeed. That is, in fact, one of the points Williams was making with George's example (1973: 112-13, 131). There is a reason, then - a consequentialist reason - to leave people morally free to turn down jobs, even 


\section{MATTHEW RENDALL}

when they could do more good by taking the job and giving much or most of the earnings away. No comparably strong justification exists for leaving them free to practise harmful occupations but to retain the salary. The world will not be a better place if we permit people to make money from noxious jobs without disgorging the profits. Analogously, there is a strong reason to allow societies to shape their own ways of life. To demand that each should build its entire economy around whatever would internationally maximise utility would be almost as oppressive as to demand it of individuals. The same is not true of allowing states to retain benefits unjustly produced at other countries' expense.

Beneficiaries of unjust enrichment, then, ought to disgorge the gains. One might think that this would require George to give up his whole salary. After all, every bit of it comes from work that harms people. Most of us, however, think that George could defensibly refuse the job. If he were required to surrender his entire salary, he surely would refuse. The consequences would be worse, both because the other chemist would pursue the work more assiduously, and because the latter would disgorge none of his gains at all. The moral code with the best results, then, will require agents to surrender gains from unjust enrichment, but allow them to retain enough that they do not lose out, or even are modestly better off, in comparison with their next-best permissible option. ${ }^{9}$ It is widely agreed that in cases of unjust enrichment, one must disgorge only up to the point that one is no longer benefiting (Butt, 2007: 142; Page, 2012: 309-10). ${ }^{10}$ High-emitting countries ought to give up their gains until they are as well-off, or modestly better-off, than they would be if their emissions matched their fair international share (see Lawford-Smith, 2014). Given the large emissions-cuts that industrialised countries would have to make under any fair and effective international climate regime, no precise calculations are needed to see that states which go on emitting at high levels ought to give up far more than they are presently doing.

Such large sums could make a tremendous difference. Given enough sidepayments by the industrialised countries, a worldwide agreement to limit emissions might succeed. Southern countries have shown openness to such an agreement, provided that they benefit enough. Under a cap, if the North wished to maintain a high level of emissions, this would require it to transfer substantial sums through carbon trading (Davidson, 2008: 78). The North could also

9. It is true that when one agent harms another, she may be obliged to make compensation even when it leaves her worse off. George, however, will not harm the victims of chemical weapons if he takes the job; indeed, he will leave some prospective victims better off than they would be if he refused. His obligation to disgorge arises from unjust enrichment.

10. This implies that if the job were poorly paid enough, George would have no obligation to disgorge any of his gains. This may seem hard to believe. But if the pay were so poor to make the job no better than being unemployed, then we would wonder why he was taking the job at all. Indeed, other considerations - the presumption against going into harmful professions, the risk that it would corrupt him or make it harder to speak out against chemical weapons would give grounds to turn it down. 
encourage compliance by funding mitigation and adaptation - including afforestation and renewable energy - in the developing world. The North should pay for mitigation, but much of the money should be spent in the South (see Hohl and Roser, 2011: 497). ${ }^{11}$ Breakthroughs in alternative energy could make it in states' direct economic interest to cut emissions (Shue 2013: 396-99). ${ }^{12}$ Yet worldwide government spending on energy R\&D has actually fallen since the 1970s (Nemet and Kammen, 2007; Sarewitz and Pielke, Jr., 2008; Fölster and Nyström, 2010: 233). There is still time to make amends. David King and Richard Layard (2013), for example, have recently argued for a push to develop solar energy, with the targets of making its cost competitive with that of fossil fuels, and supplying twenty-five per cent of total worldwide energy use by 2030 . A mere fraction of the wealth that the North derives from its excessive emissions would fund much research indeed.

\section{IS DISGORGEMENT REALISTIC?}

Demands for disgorgement on this scale may seem unrealistic. 'We can't wait to hear Mr Obama tell Americans that he wants them to pay higher taxes', scoffs the Wall Street Journal, 'so the U.S. can pay China to become more energy efficient and thus more economically competitive' (2009b). In fact, this is hardly absurd: any international agreement on climate change will need China's participation, and side payments to get Beijing on board might be an efficient way for Washington to discharge its obligations (Gesang, 2011: 199200). But understood as a claim about political realities, the argument has a point. Eric Posner and David Weisbach have recently argued that any viable international climate agreement must leave all parties roughly as well off as they would be in its absence (2010: 179). If so, then this would preclude redistribution from the rich countries on the scale that justice demands.

Their diagnosis may, however, be too pessimistic: it overlooks the possibility of financing a significant share of the mitigation through intergenerational

11. In a Wall Street Journal op-ed during the Copenhagen climate conference, Richard Muller (2009) suggested that the West might 'subsidize CCS [carbon capture and storage] in China or pay to make its plants CCS ready' and '[t]he bulk of our effort is best directed at helping the emerging economies conserve energy and move rapidly toward efficient solar, wind and nuclear power'. He then maintained that 'make-the-West-bear-the-burden Copenhagen proposals are meaningless'. Why?

12. '[E]ven if a fantastic renewable energy technology enters the market in the United States', Benjamin Hale warns, 'this does not give places like Argentina or Saudi Arabia a reason to stop pumping oil. It only increases their incentives to pump until all extractable oil is consumed' (2011: 380). But nothing would prevent Northern states from transferring that technology to the South, provided it was developed with public funds. Even if one doubts that the North would actually do this, if cost-effective alternative energy became widespread and mass-produced in the United States or Europe, it is hard to believe it would not soon spread to China or India, as Bernward Gesang points out (2011: 212-14). 


\section{MATTHEW RENDALL}

transfers (Foley, 2007; Rendall, 2011a; Broome, 2012: 43-48, 154-55; Rozenberg et al., 2013; Caney, 2014: 332-38). This could mean increasing the public debt, decreasing public and private investment in other sectors, or increased use of natural resources - in each case, shifting part of the burden to future generations in the rich countries (Broome, 2012: 44-45; Zelenak, 2009: 1361). Some will think that this would right an international injustice at the expense of creating an intergenerational one. John Broome, who favours such a policy on pragmatic grounds, nonetheless laments that 'emitters are paid to reduce their emissions by the receivers [of harm]....Receivers in effect bribe emitters not to harm them' (2012: 46). Yet running up debt at the expense of future generations cannot harm them at all, because of the non-identity problem. The relevant questions are not whether it will cause harm, but whether doing so will cause a loss in total utility, and whether it is unfair.

Because marginal utility from income declines as people get richer, taking resources from future rich people to protect future poor people from climate change should increase total welfare (see Gesang, 2011: 189-90, 198-99). Provided that we avert disaster, the rich countries are also likely to be much richer in the future than they are at present, regardless of whether we pass on some of the costs of mitigation (Rendall, 2011a).$^{13}$ Furthermore, part of the stock of emissions that threatens future people arose from the actions of our ancestors. It is not the present generation's fault that the need to slash carbon emissions comes during our watch (Malnes, 1995: 108). Why should we bear the entire burden of the transition to a low-carbon economy - a transition which will mainly benefit our descendants? It is only fair that the rich of the future should share the load - just as it is also only fair to future people to ensure that enough mitigation takes place. Shifting part of the cost to the future may render mitigation more politically feasible (Rendall, 2011a: 893; Broome, 2012: 47-48; Rozenberg et al., 2013).

\section{CONCLUSION}

Climate change is likely to kill millions of humans, and still more non-humans. It may kill orders of magnitude more (Broome, 2010: 106-9; Weitzman, 2011). By any standard, this is an appalling injustice. Yet if carbon leakage should prove as severe as critics of the Kyoto process suggest, then Northernemissions curbs will be exploited by industrialising countries, while doing little good. The mistake of GWAND's proponents is to assume that this gets

13. Opponents of strong mitigation policies sometimes invoke this consideration as a reason for doing little about climate change. Thus Bjørn Lomborg argues that it would be more efficient to spend the same money on helping poor people in the South today (2007: 55). This ignores both harm to non-humans, and the low-probability but nonetheless serious risk that runaway global warming will leave the future impoverished instead. 
the high-emitters off the hook. Business as usual is not a defensible option. Even if the North does not make up for all its unjust enrichment, giving up just a fraction would amount to far more than it has done so far (see Page, 2012: 325-27). For too long, critics of carbon mitigation have got away with claiming that carbon leakage justifies business as usual. That is not the case. The North may be justified in maintaining high emissions. But so long as it refuses to disgorge the profits, it is retaining goods which belong to others.

\section{REFERENCES}

Adams, R.M. 1976. 'Motive utilitarianism'. Journal of Philosophy 73: 467-81. CrossRef

Anwander, N. 2005. 'Contributing and benefiting: Two grounds for duties to the victims of injustice'. Ethics and International Affairs 19: 39-45. CrossRef

Baer, P. 2011. 'International justice'. In J.S. Dryzek, R.B. Norgaard and D. Schlosberg (eds), The Oxford Handbook of Climate Change and Society, pp. 323-37. Oxford: Oxford University Press.

Bailey, A.D. 2011. 'The nonworseness claim and the moral permissibility of betterthan-permissible acts'. Philosophia 39: 237-50. CrossRef

Brooks, D. 1989. 'On living in an unjust society'. Journal of Applied Philosophy 6: 31-42. CrossRef

Broome, J. 1990/91. 'Fairness'. Proceedings of the Aristotelian Society, New Series 91: 87-101.

Broome, J. 2010. 'The most important thing about climate change'. In J. Boston et al. (eds.), Public Policy: Why Ethics Matters, pp. 101-16. Canberra: ANU E Press.

Broome, J. 2012. Climate Matters: Ethics in a Warming World. New York, NY: W.W. Norton.

Butt, D. 2007. 'On benefiting from injustice'. Canadian Journal of Philosophy 37: 129-52. CrossRef

Caney, S. 2006. 'Environmental degradation, reparations, and the moral significance of history'. Journal of Social Philosophy 37: 464-82. CrossRef

Caney, S. 2010. 'Global climate change and the duties of the advantaged', Critical Review of International Social and Political Philosophy 13: 203-28. CrossRef

Caney, S. 2014. 'Climate change, intergenerational equity and the social discount rate', Politics, Philosophy \& Economics 13: 320-42. CrossRef

Coon, C.E. 2001. 'Why President Bush is right to abandon the Kyoto Protocol'. Heritage Foundation Backgrounder 1437. Online at: http://www.heritage.org/research/reports/2001/05/president-bush-right-to-abandon-kyoto-protocol (accessed 1 April 2015).

Das, R. 2014. 'Has industrialization benefited no one? Climate change and the non-identity problem'. Ethical Theory and Moral Practice 17: 747-59. CrossRef 


\section{MATTHEW RENDALL}

Davidson, M.D. 2008. 'Parallels in reactionaryargumentation in the U.S. Congressional Debates on the abolition of slavery and the Kyoto Protocol'. Climatic Change 86: 67-82. CrossRef

Eckersley, R. 2010. 'The politics of carbon leakage and the fairness of border measures'. Ethics \& International Affairs 24: 367-93. CrossRef

Elliott, F., A. Thomson and R. Sylvester. 2013. 'Osborne threatens to put brake on green taxes; Chancellor proposes to keep energy prices in check'. The Times, 28 September.

Feinberg, J. 1988. Harmless Wrongdoing. Oxford: Oxford University Press.

Feldman, F. 1995a. 'Adjusting utility for justice: A consequentialist reply to the objection from justice'. Philosophy and Phenomenological Research 55: 567-85. CrossRef

Feldman, F. 1995b. 'Justice, desert, and the Repugnant Conclusion'. Utilitas 7: 189206. CrossRef

Foley, D.K. 2007. 'The economic fundamentals of global warming'. SFI Working Paper 2007-12-044, Santa Fe Institute. Online at: http://www.santafe.edu/media/ workingpapers/07-12-044.pdf (accessed 1 April 2015).

Fölster, S. and J. Nyström. 2010. 'Climate policy to defeat the green paradox'. Ambio 39: 223-35. CrossRef

Gardiner, S.M. 2011. A Perfect Moral Storm: The Ethical Tragedy of Climate Change. New York, NY: Oxford University Press. CrossRef

Gesang, B. 2011. Klimaethik. Berlin: Suhrkamp.

Glover, J. 1975. "“It makes no difference whether or not I do it"'. Proceedings of the Aristotelian Society, Supplementary Volumes 49: 171-90.

Goldenberg, S. 2014. 'CO emissions are being "outsourced" by rich countries to rising economies'. Guardian, 19 January.

Gosseries, A. 2004. 'Historical emissions and free riding'. Ethical Perspectives 11: 36-60. CrossRef

Hale, B. 2011. 'Nonrenewable sources and the inevitability of outcomes'. Monist 94: 369-90. CrossRef

Hardin, G. 1968/2009. 'The tragedy of the commons'. Journal of Natural Resources Policy Research 1: 243-53. CrossRef

Hare, R.M. 1965. Freedom and Reason. Oxford: Oxford University Press. CrossRef

Hare, R.M. 1981. Moral Thinking: Its Levels, Method, and Point. Oxford: Clarendon Press. CrossRef

Harvey, F. 2011. 'Autumn Statement: George Osborne slams “costly” green policies'. Guardian, 29 November.

Hohl, S. and D. Roser. 2011. 'Stepping in for the polluters? Climate justice under partial compliance'. Analyse und Kritik 33: 477-500.

Huseby, R. 2015. 'Should the beneficiaries pay?' Politics Philosophy \& Economics 14(2): 209-225. CrossRef

Jackson, F. 1997. 'Which effects?' In J. Dancy (ed.), Reading Parfit, pp. 42-53. Oxford: Blackwell. 


\section{CARBON LEAKAGE AND THE ARGUMENT FROM NO DIFFERENCE}

Jamieson, D. 2007. 'When utilitarians should be virtue theorists'. Utilitas 19: 160-83. CrossRef

Johnson, C.D. 1991. Moral Legislation: A Legal-Political Model for Indirect Reasoning. Cambridge: Cambridge University Press.

Kent, A. 2004. 'A critical look at risk assessments for global catastrophes'. Risk Analysis 24: 157-68. CrossRef

King, D. and R. Layard. 2013. 'We must harness the power of the sun'. Observer, 29 September.

Lawford-Smith, H. 2014. 'Benefiting from failures to address climate change'. Journal of Applied Philosophy 31: 392-404. CrossRef

Lomborg, B. 2007. Cool It: The Skeptical Environmentalist's Guide to Global Warming. London: Marshall Cavendish.

Malnes, R. 1995. Valuing the Environment. Manchester: Manchester University Press.

Mayer, R. 2007. 'What's wrong with exploitation?' Journal of Applied Philosophy 24: 137-50. CrossRef

Meyer, L.H. and D. Roser. 2010. 'Climate Justice and Historical Emissions'. Critical Review of International Social and Political Philosophy 13: 229-53. CrossRef

Muller, R. 2009. 'Naked Copenhagen'. Wall Street Journal, 12 December.

Murkowski, F.H. 2000. 'The Kyoto Protocol is not the answer to climate change'. Harvard Journal on Legislation 37: 345-67.

Murphy, L.B. 2000. Moral Demands in Nonideal Theory. New York, NY: Oxford University Press.

Nemet, G.F. and D.M. Kammen. 2007. 'U.S. energy research and development: Declining investment, increasing need, and the feasibility of expansion'. Energy Policy 35: 746-55. CrossRef

Norcross, A. 2005. 'Harming in context'. Philosophical Studies 123: 149-73. CrossRef

Nozick, R. 1974. Anarchy, State, and Utopia. New York, NY: Basic Books.

Page, E.A. 2012. 'Give it up for climate change: A defence of the beneficiary pays principle'. International Theory 4: 300-30. CrossRef

Pearson, C.S. 2011. Economics and the Challenge of Global Warming. New York: Cambridge University Press. CrossRef

Posner, E.A. and D. Weisbach. 2010. Climate Change Justice. Princeton, NJ: Princeton University Press.

Price, R.M. 1997. The Chemical Weapons Taboo. Ithaca, NY: Cornell University Press.

Rendall, M. 2011a. 'Climate change and the threat of disaster: The moral case for taking out insurance at our grandchildren's expense'. Political Studies 59: 884-99. CrossRef

Rendall, M. 2011b. 'Non-identity, sufficiency and exploitation'. Journal of Political Philosophy 19: 229-47. CrossRef

Rozenberg, J., S. Hallegatte, B. Perrissin-Fabert and J.-C. Hourcade. 2013. 'Funding low-carbon investments in the absence of a carbon tax'. Climate Policy 13: 134-41. CrossRef

Sarewitz, D. and R.J. Pielke, Jr. 2008. 'The steps not yet taken'. In D.L. Kleinman, K.A. Cloud-Hansen, C. Matta and J. Handelsman (eds), Controversies in Science and 


\section{MATTHEW RENDALL}

Technology Volume 2: From Climate to Chromosomes, pp. 329-51. New Rochelle, NY: Mary Ann Liebert.

Sartorio, C. 2006. 'Disjunctive causes'. Journal of Philosophy 103: 521-38.

Shue, H. 2013. 'Climate hope: Implementing the exit strategy'. Chicago Journal of International Law 13: 381-402.

Silverstein, H.S. 1979. 'Utilitarianism and group coordination'. Nô̂s 13: 335-60. CrossRef

Vallentyne, P. 1995. 'Taking justice too seriously'. Utilitas 7: 207-16. CrossRef

Vanderheiden, S. 2008. Atmospheric Justice: A Political Theory of Climate Change. New York, NY: Oxford University Press. CrossRef

Wall Street Journal. 2009a. 'Cap and trade war'. Unsigned, 30 March.

Wall Street Journal. 2009b. 'Copenhagen's lesson in limits'. Unsigned, 19 December.

Wall Street Journal. 2009c. 'More cap and trade war'. Unsigned, 12 August.

Weitzman, M.L. 2011. 'Fat-tailed uncertainty in the economics of catastrophic climate change'. Review of Environmental Economics and Policy 5: 275-92. CrossRef

Wertheimer, A. 1996. Exploitation. Princeton, NJ: Princeton University Press.

Williams, B. 1973. 'A critique of utilitarianism'. In J.J.C. Smart and B. Williams, Utilitarianism: For and Against, pp. 77-150. Cambridge: Cambridge University Press.

Zelenak, L. 2009. 'Does intergenerational justice require rising standards of living?' George Washington Law Review 77: 1358-82. 